\title{
Akibat Hukum Perbuatan Aparat Pemerintah yang Tidak Sah Dalam melaksanakan Pemerintahan.
}

\section{Oleh I Komang Darman*}

\begin{abstract}
Abstrak
Perbuatan Aparat pemerintah yang termasuk dalam perbuatan hukum dapat berupa : perbuatan hukum menurut hukum privat dan perbuatan hukum menurut hukum publik. Perbuatan hukum menurut hukum privat dalam hukum tata pemerintahan terjadi perdebatan apakah merupakan lapangan ilmu hukum tata pemerintahan atau bukan. Namun yang dibahas dalam lingkup hukum tata pemerintahan yakni perbuatan hukum menurut hukum publik.

Akibat Hukum kewenangan yang tidak sah ialah batal demi hukum, begitu juga dengan konsekuensi yuridis perbuatan hukum aparat pemerintah yang dinyatakan batal demi hukum pada mulanya didasari dengan kewenangan yang tidak sah dan tidak memenuhi syarat-syarat ketentuan yang harus terpenuhi agar suatu perbuatan aparat pemerintah dinyatakan sah. akibat hukum atau sanksi nya berupa semua perbuatan yang dilakukan dianggap belum pernah ada sehingga segala sesuatunya harus dikembalikan seperti sedia kala atau alternative kedua memakai batal nisbi yakni sebagian perbuatan dianggap sah dan sebagian lagi diputuskan batal.
\end{abstract}

Kata Kunci: Perbuatan hukum,Aparat Pemerintah dan Akibat Hukum.

\section{PENDAHULUAN}

Negara merupakan suatu bentuk organisasi masyarakat yang hidup dalam suatu wilayah dan mempunyai tujuan yang sama. Terdapat banyak rumusan dari para pakar mengenai tujuan negara. Menurut pendapat Aristoteles, tujuan negara adalah supaya warga negaranya dapat hidup baik dan bahagia ${ }^{1}$. Tujuan negara untuk memelihara dan menjamin hak- hak asasi manusia. Negara menjamin terlaksananya kepentingan umum di dalam keadaan hukum. Demikan juga Menurut Franz Magnis Suseno, tujuan negara adalah memajukan kepentingan- kepentingan

\footnotetext{
${ }^{1}$ Soehino, 1999, Ilmu Negara, Liberty, Yogyakarta, hlm. 24.
} 
masyarakat seoptimal mungkin berdasarkan solidaritas seluruh masyarakat dengan menjamin adanya kebebasan dari seluruh anggota masyarakat dan tidak mendapatkan kesewenangwenangan dari penguasa ${ }^{2}$. Tujuan negara Kesatuan Republik Indonesia adalah membentuk suatu pemerintahan negara Indonesia yang melindungi segenap bangsa Indonesia dan seluruh tumpah darah Indonesia dan untuk memajukan kesejahteraan umum, mencerdaskan kehidupan bangsa dan ikut melaksanakan ketertiban dunia yang berdasarkan kemerdekaan, perdamaian abadi dan keadilan sosial. Menurut pendapat Miriam Budiardjo, tujuan negara (terlepas dari apapun ideologinya) meliputi mengusahakan kesejahteraan dan kemakmuran rakyatnya dan menegakkan keadilan melalui badan- badan pengadilan ${ }^{3}$.

Dalam rangka mencapai tujuannya, negara dijalankan oleh suatu pemerintah, dengan kata lain pemerintah adalah pelaksana kekuasaan negara. Pemerintah merupakan suatu organisasi yang berwenang untuk merumuskan dan melaksanakan keputusan- keputusan yang mengikat bagi seluruh penduduk di dalam wilayahnya. Kekuasaan pemerintah tersebut rawan disalahgunakan oleh orang- orang yang menjadi pejabat/ aparat pemerintah. Sebagai respon atas kesewenang- wenangan penguasa/ pemerintah timbul konsep negara hukum (rechstaat). Menurut pendapat Frederich Julius Stahl, salah satu unsur dalam konsep negara hukum adalah adanya peradilan administrasi negara yang berwenang menangani kasus perbuatan melanggar hukum oleh pemerintah ${ }^{4}$.

1. Dalam menjalankan tugasnya, aparat pemerintah tidak lepas dari potensi untuk melakukan perbuatan yang melanggar atau tidak sah jika ditinjau dari segi hukum. James Madison, dalam tulisannya yang berjudul Federalist Papers menyatakan bahwa:

2. "if men were angels, no government would be necessary. If angels were to govern men neither external nor internal controls on government would be necessary”.

3. Terjemahan bebas:

\footnotetext{
${ }^{2}$ Hassan Suryono, 2008, Ilmu Negara Suatu Pengantar ke Dalam Politik Hukum Kenegaraan, UNS Press, Surakarta, hlm. 31.

${ }^{3}$ Miriam Budiardjo, 2005, Dasar- Dasar Ilmu Politik, Gramedia Pustaka Tama, Jakarta, hlm. 46.

$\left.{ }^{4}\right]$ Winahyu Erwiningsih, makalah "Peranan Hukum dalam Pertanggung jawaban Perbuatan Pemerintahan (Bestuurshandeling) Suatu kajian dalam Kebijakan Pembangunan Hukum".
} 
4. "Jika manusia adalah malaikat maka tidak perlu ada pemerintah. Jika malaikat yang memerintah manusia maka pengawasan/ pengendalian/ kontrol dari luar (eksternal) atau dari dalam (internal) pada pemerintah tidak diperlukan". 5

Unsur aparat pemerintah merupakan elemen yang sangat penting dalam hukum tata pemerintahan, karena jika diibaratkan sebuah organisasi aparat pemerintah itu bisa dikatakan adalah pengurus dalam suatu organisasi yang sangat berperan penting dalam tujuan yang mulia dari suatu organisasi tersebut. Jika diibaratkan dalam sebuah kendaraan mobil, aparat pemerintah itu adalah seorang supir yang mengemudikan laju kendaraan mobil agar sampai dengan selamat pada tujuan yang ingin dicapai.

Begitu pentingnya aparat pemerintahan dalam sebuah negara sehingga aparat pemerintah itu memliki kewenangan untuk menjalankan fungsinya yang telah diatur didalam peraturan perundang-undangan. Dalam mempelajari hukum tata pemerintahan kita harus mengetahui dan memahami mengenai objek hukum tata pemerintahan ialah pemerintah. Menurut Prof. Muchsan aspek untuk membahas pemerintah ada 5 (lima) aspek yaitu :

1. Aspek Struktur organisasi/lembaga pemerintah

2. Aspek Fungsi/kefungsian aparat pemerintah

3. Aspek Kewenangan aparat pemerintah

4. Aspek Perbuatan pemerintah

5. Aspek Sarana Negara

6. Aspek Sengawasan

1. Kekuasaan

2. Perbuatan hukum

3. Dapat dipaksakan pelaksanaannya

Perbuatan yang dipaksakan biasa disebut dengan perbuatan sepihak, kewenangan yang dimiliki oleh pemerintah ialah kewenangan atributif dan kewenangan non atributif, dari segi terjadinya kewenangan atributif tercipta karena Peraturan Perundang-undangan sedangkan kewenangan non atributif tercipta atau bersumber dari pelimpahan wewenang. Keduanya merupakan kewenangan yang absah, perbedaannya ada pada perolehannya, kewenangan atributif mempunyai ciri yang bersifat "kekal dan abadi" maksudnya adalah saat berakhirnya 
kewenanangan tersebut kabur. Ada dua jenis kewenangan non atributif yakni mandaat dan delegasi. Mandaat adalah kewenangan yang beralih kepada mandataris hanya sebagian wewenang saja sedangkan Delegasi adalah wewenang yang beralih sepenuhnya. Yang perlu dicatat adalah apabila kewenangan tersebut dicampurkan dengan privat maka menjadi penyalahgunaan wewenang. Perbuatan hukum atau juga sering disebut perbuatan pemerintah adalah wujud dari kewenangan. Perbuatan hukum atau perbuatan pemerintah dapat dikelompokkan menjadi dua macam perbuatan, yakni :

1. Rechtelijk handling; Perbuatan yang menimbulkan akibat hukum

2. Feitelijk Handling: Perbuatan yang tidak mampu menimbulkan perbuatan hukum

Tindakan hukum pemerintahan adalah tindakan yang dilakukan oleh Badan atau Pejabat Tata Usaha Negara dalam rangka melaksanakan urusan pemerintahan. Tindakan pemerintahan memiliki beberapa unsur yaitu dilakukan oleh aparat pemerintah dalam kedudukannya sebagai penguasa maupun sebagai alat perlengkapan pemerintahan (bestuurs-organen) dengan prakarsa dan tanggung jawab sendiri.

\section{PEMBAHASAN}

\section{II.1 Bentuk Perbuatan Hukum Pemerintah Dalam melaksanakan Pemerintahan}

Dalam pengertian sempit, pemerintah identik dengan pelaksana kekuasaan eksekutif. Menurut pandangan klasik, pelaksana kekuasaan eksekutif adalah pihak- pihak yang melaksanakan kebijakan- kebijakan publik (kenegaraan dan atau pemerintahan) melalui peraturan perundang- undangan yang telah dibuat oleh pelaksana kekuasaan legislatif. Secara teoritis pemerintah mempunyai kedudukan sebagai bagian dari organisasi negara dan sebagai administratur negara. Sebagai organ negara pemerintah bertindak untuk dan atas nama negara. Sedangkan sebagai administrasi negara, pemerintah dapat bertindak baik di lapangan pengaturan (regelen) maupun dalam lapangan pelayanan (bestuuren) ${ }^{6}$. 'Administrasi' (Negara) adalah badan atau jabatan dalam lapangan kekuasaan eksekutif yang mempunyai kekuasaan mandiri berdasarkan hukum untuk melakukan tindakan-tindakan pemerintahan baik di lapangan pengaturan, maupun penyelenggaraan administrasi negara. Menurut S. Prajudi Atmosudirdjo, Birokrasi (Bureaucracy) atau Administrasi Negara atau Tata Usaha Negara (TUN) meliputi tiga hal, yaitu:

$6 \quad$ Iskatrinah, Pelaksanaan Fungsi Hukum Administrasi Negara Dalam Mewujudkan Pemerintahan Yang Baik, Litbang Pertahanan Indonesia, Balitbang DepHan 2004. 
a. aparatur negara, aparatur pemerintah, atau institusi politik (kenegaraan);

b. fungsi atau aktivitas melayani atau sebagai kegiatan pemerintah operasional; dan

c. proses teknis penyelenggaraan Undang-undang. ${ }^{7}$

Ketiga unsur tersebut dapat diwujudkan dalam kenyataan melalui aktivitas pejabat birokrasi atau "aparatur negara yang menjalankan tugas administrasi melalui pengambilan keputusan-keputusan administratif (administratieve beschikking) yang bersifat individual, kasual, faktual, teknis penyelenggaraan, dan tindakan administratif, yang bersifat organisasional, manajerial, informasional atau operasional. Konsep Negara yang telah kita sepakati adalah Negara yang tidak menghilangkan kepentingan rakyatnya. Artinya dalam setiap perilaku Negara harus mencerminkan apresiasi dari kepentingan dan kebutuhan rakyatnya sendiri. Jika Negara Indonesia saat ini sudah lupa akan tujuan utama yaitu mensejahterahkan rakyatnya dari berbagai keterpurukan, yaitu kemiskinan dan ketidak berdayaan secara sosial dan politik, maka hal ini sudah menyalahi dari mkontrak yang sudah kita sepakati bersama. ${ }^{8}$

Dengan kekuasaan tersebut dalam melakukan aktivitasnya, pemerintah melakukan dua macam tindakan, tindakan biasa dan tindakan hukum. Dengan kata lain bahwa, bentuk perbuatan pemerintahan atau bentuk tindakan administrasi negara yang secara garis besar dapat dibedakan menjadi dua macam, yaitu:

1. Perbuatan hukum

2. Bukan perbuatan hukum

Perbuatan pemerintah yang termasuk dalam perbuatan hukum dapat berupa: perbuatan hukum menurut hukum privat dan perbuatan hukum menurut hukum publik. Perbuatan hukum menurut hukum privat dalam hukum tata pemerintahan terjadi perdebatan apakah merupakan lapangan ilmu hukum tata pemerintahan atau bukan. Namun yang dibahas dalam lingkup hukum tata pemerintahan yakni perbuatan hukum menurut hukum publik. Perbuatan hukum menurut hukum publik ini dibagi dalam dua macam :

1. Perbuatan hukum publik yang bersegi satu (1) (eenzijdige publiekrechtelijke handeling).

\footnotetext{
7 Eman Suparman, makalah "Badan Peradilan Untuk Keputusan Birokrasi”, http://resources.unpad.ac.id/unpadcontent/uploads/publikasi_dosen/2K\%20Pengantar-UU-TUN-FoMed.pdf, diakses 12 Juli 2017

8 E.Utrecht. 1986, Pengantar Hukum Administrasi Negara Indonesia. Pustaka Tinta Mas. Surabaya. Hlm $109-113$.
} 
Artinya hukum publik itu lebih merupakan kehendak satu pihak saja yaitu pemerintah menurut mereka para ahli hukum tata pemerintahan tidak ada perbuatan publik yang bersegi dua, tidak ada perjanjian, yang diatur oleh hukum publik. Itulah sebabnya tidak ada perjanjian menurut hukum publik. Sebab hubungan hukum hanya berasal dari satu pihak saja yakni pemerintahan dengan cara menentukan kehendak sendiri.

2. Perbuatan hukum publik yang bersegi dua (2) (tweetzijdige publiekrechtelijke handeling). Ada beberapa sarjana yang mengakui adanya hukum publik bersegi dua yakni Van der pot, Kranenberg-Vegting, Wiarda, dan Donner. Mereka member contoh tentang adanya kortverband contract (perjanjian kerja jangka pendek) yang diadakan seorang swasta sebagai pekerja dengan pihak pemerintah sebagai pihak pemberi pekerjaan.

Menurut Prof. Muchsan unsur-unsur perbuatan hukum pemerintahan sebagai berikut:

a. Perbuatan itu dilakukan oleh aparat pemerintah dalam kedudukannya sebagai penguasa maupun sebagai alat perlengkapan pemerintahan (bestuurorganen) dengan prakarsa dan tanggung jawab sendiri.

b. Perbuatan tersebut dilaksanakan dalam rangka menjalankan fungsi pemerintahan.

c. Perbuatan tersebut dimaksudkan sebagai sarana untuk menimbulkan akibat hukum dibidang hukum administrasi.

d. Perbuatan yang bersangkutan dilakukan dalam rangka pemeliharaan kepentingan negara dan rakyat.

e. Parameter Yuridis Terhadap Perbuatan Hukum Yang Sah

Perbuatan hukum oleh aparat pemerintah adalah perbuatan atau tindakan yang dilakukan oleh pejabat Tata Usaha Negara dalam rangka melaksnakan urusan pemerintahan. Salah satu contoh dari perbuatan aparat pemerintah ialah ketetapan. Ketetapan dibagi menjadi dua macam yakni :

1. Ketetapan sah (rechtsgeldige beschikking)

Syarat-syarat yang harus terpenuhi agar ketetapan adalah ketetapan yang sah (voorwaarden voor de rechtsgeldigheid der beschickking) menurut Van der Pot :

2. Ketetapan harus dibuat oleh alat (organ) yang berkuasa (bevoegd) membuatnya 
3. Dalam pembentukan kehendak dari alat negara yang mengeluar kan suatu ketetapan, tidak boleh ada kekurngan yuridis, kekurangan yuridis dapat disebabkan karena salah kira (dwaling), paksaan (Dwang) dan tipuan(bedrog)

4. Ketetapan yang dimaksud harus diberi bentuk (vorm) yang sesuai dengan yang ditetapkan dalam peraturan yang menjadi dasarnya dan pembuatan keputusan tersebut juga harus memperhatikan cara/prosedur pembuatan keputusan/ketetapan yang dimaksud

5. Isi dan tujuan dari ketetapan harus sesuai dengan isi dan tujuan dalam peraturan dasarnya.

6. Ketetapan tidak sah (niet- rechtsgeldige beschikking)

Ketetapan tidak sah itu dapat berupa :

a. Ketetapan Batal demi hukum (nietig van recht wege).

b. Ketetapan yang batal mutlak (absoluut nietig).

c. Ketetapan yang dapat dibatalkan (vernietigbaar)

Batal (nietig) berarti bahwa bagi hukum perbuatan itu dianggap tidak pernah ada. Batal ini disebut batal mutlak. Batal nisbi (relatief nietig) suatu perbuatan bagi hukum dapat dikatakan batal nisbi, bilamana pembatalan perbuatan itu yang bagi hukum batal sama sekali hanya dapat dituntut oleh beberapa orang tertentu saja.

Secara umum kelaziman perbuatan aparatur pemerintah yang dianggap tidak sah, menurut Felix A. Nigro dapat dikategorikan dalam 9 bentuk pelanggaran yaitu:

1. Ketidakjujuran

2. Berperilaku tidak etis

3. Mengesampingkan hukum

4. Memperlakukan pegawai secara tidak patut

5. Melanggar prosedur hukum

6. Tidak menjalin kerjasama yang baik dengan pihak legislatif

7. Pemborosan dalam penggunaan sumber daya

8. Menutup-nutupi kesalahan yang dilakukan oleh aparatur

9. Kegagalan untuk melakukan inisiatif dan terobosan yang positif

Menjalankan kewenangan dari aparatur pemerintah, terdapat pembatasanpembatasan yang diperlukan agar di dalam menjalankan kewenangannya tersebut, aparatur pemerintah tidak menyalahgunakan kekuasaan dan kewenangan yang dimilikinya (abuse of 
power). Untuk itu, diperlukan suatu kategori atau bentuk pengetahuan terhadap kategori, kapan sebuah kewenangan dianggap tidak sah atau tidak berjalan sebagaimana ketentuan yang ada.

Menurut Prof. Muchsan penyebab ketidakwenangan aparat pemerintah yaitu:

1. Ratione Material, yakni kewenangan aparatur pemerintahan yang tidak sah dikarenakan substansi kewenangannya.

2. Ratione Loccus, yakni ketidakwenangan seorang aparatur pemerintahan dikarenakan wilayah hukumnya.

3. Ratione Temporis, ketidakwenangan seorang aparatur pemerintahan dikarenakan lewat waktu, atau yang pada umumnya sering kita istilahkan daluarsa.

Dapat dikatakan perbuatan pemerintah yang tidak sah ialah jika suatu perbuatan aparat pemerintah yang tidak berdasar pada syarat-syarat sahnya yang harus dipenuhi oleh suatu ketetapan yang disebutkan seperti pendapat Van der Pot diatas dan juga melupakan asas-asas pemerintahan umum yang baik, sehinggga perbuatan hukum aparat pemerintah itu dinyatakan tidak sah. Begitu juga dalam menentukan sah atau tidaknya suatu perbuatan aparat pemerintah dapat dilihat dari retione material, retione locus dan retione temporis yang merupakan sabab keidakberwenangan aparat pemerintah dalam melakukan perbuatan hukum tata pemerintahan yang baik.

Dalam ranah Hukum Tata Pemerintahan (bestuursrecht), terdapat 3 (tiga) teori kebatalan (nietig Theory), yakni batal mutlak, batal demi hukum dan dapat dibatalkan. Ketiga teori ini memiliki perbedaan berdasarkan 2 (dua) aspek, yaitu

1. Berdasarkan akibat hukum yang ditimbulkan, yaitu akibat-akibat hukum yang mengikuti jika terjadi pembatalan. Hal tersebut merupakan konsekuensi logis yang muncul dan tidak dapat dihindari akibat pembatalan tersebut.

2. Lembaga atau Pejabat yang berhak menyatakan batal, yaitu mengenai kewenangan pembatalan, dalam arti siapa pejabat yang berhak untuk melakukan proses pembatalan tersebut. Untuk lebih memudahkan kita dalam mengidentifikasi pejabat siapa saja yang memiliki hak untuk membatalkan, maka kita membagi pejabat dalam bentuk yang sangat sederhana, yakni lembaga atau pejabat yudikatif, eksekutif dan legislatif.

Suatu tindakan sewenang-wenang, kalau hal itu sempat terjadi, badan pemerintahan dalam pertimbangannya mengenal kepentingan yang bersangkutan harus bersikap jujur agar 
tidak sampai manyangkut pada tindakan hukum administrasi, sehingga dengan demikian pertimbangan kepentingan dianggap tidak pernah ada

\section{II.2 Akibat hukum Perbuatan Tidak Sah Aparat Pemerintah Dalam melasanakan Pemerintahan}

Dalam menjalankan tugasnya aparat pemerintah harus selalu berpedoman pada sah atau tidaknya kewenangan untuk melakukan perbuatan hukum. Apabila kewenangan untuk melakukan perbuatan hukum tersebut sah maka hasil perbuatan hukum (dalam bentuk pembuatan suatu keputusan atau produk hukum) tetap sah (legitimate) untuk dilaksanakan. Sebaliknya, apabila kewenangan untukmelakukan perbuatan hukum tersebut tidak sah (ilegitimate) maka timbul konsekuensi bahwa perbuatan hukum tersebut menjadi batal. Kebatalan tersebut dapat dijabarkan melalui teori kebatalan (nietig theorie) sebagai berikut:

1.batal mutlak (absolute nietig).

2.batal demi hukum (nietig van rechts wege).

3.dapat dibatalkan (vernietig baar).

Ketiga kemungkinan kebatalan diatas dapat ditinjau dari dua hal, yaitu dari akibat hukum/ konsekuensi yuridis yang timbul dan dari pejabat/ aparat yang berwenang untuk menyatakan kebatalan.

1. Batal Mutlak (absolute nietig):

a. Akibat Hukum: semua perbuatan hukum Aparat Pemerintah yang pernah dilakukan dianggap belum pernah ada sehingga keadaan harus dikembalikan seperti semula.

Misalnya, seseorang menyewa rumah pada orang yang berada dibawah pengampuan karena pemboros. Setelah perjanjian berjalan beberapa waktu ternyata pengampu dari si pemboros mengetahui hal tersebut dan meminta pembatalan pada pengadilan. Permintaan pembatalan tersebut dikabulkan oleh pengadilan. Karena hal tersebut maka perbuatan sewa-menyewa tersebut dianggap tidak sah dan harus batal.

b. Pejabat yang berwenang menyatakan kebatalan: hanya pejabat yudikatif saja.

2. Batal Demi Hukum (nietig van rechts wege):

a. Akibat hukum Pembatalan Perbuatan Hukum ada dua alternatif:

- Semua perbuatan hukum yang pernah dilakukan oleh Aparat Pemerintah dianggap belum pernah ada. 
- Sebagian perbuatan aparat pemerintah dinyatakan sah, sedangkan sebagian yang lain dinyatakan batal.

Misalnya, dalam kasus jaksa Agung Hendarman Supandji yang tetap bertugas walaupun telah lewat masa jabatannya. Mahkamah Konstitusi (MK) memutuskan bahwa Hendarman Supandji diberhentikan. Saat pembacaan putusan, MK menyatakan bahwa sejak palu putusan diketok maka Hendarman Supandji tidak lagi berwenang sebagai Jaksa Agung. Segala perbuatan hukum yang dilakukannya sebagai Jaksa Agung dalam kurun waktu akhir masa jabatan sampai dengan saat putusan dinyatakan tetap sah.

b.Pejabat yang berwenang menyatakan kebatalan: pejabat yudikatif dan eksekutif.

\section{Dapat Dibatalkan (vernietig baar):}

a. Akibat Hukum: seluruh perbuatan hukum yang telah dilakukan dianggap sah. Perbuatan hukum yang belum dilakukan dinyatakan tidak sah.

b. Pejabat yang berwenang menyatakan kebatalan: pejabat yudikatif, eksekutif dan legislatif.

Berdasarkan hal tersebut timbul pertanyaan: "suatu perbuatan hukum termasuk dalam kebatalan yang mana?" atau "bagaimanakah menggolongkan/mengklasifikasikan suatu perbuatan hukum dalam kemungkinan kebatalan?”. Untuk menggolongkan, dipakai kriteriakriteria sebagai berikut:

d. Syarat mutlak (syarat yang harus ada):

Misalnya, syarat mutlak dalam perkawinan adalah "antara laki- laki dan perempuan”.

e. Syarat relatif (pelengkap):

Misalnya, syarat untuk menjadi hakim untuk laki-laki bertinggi badan minimal $165 \mathrm{~cm}$.

Jika tidak memenuhi syarat mutlak maka suatu perbuatan hukum yang dilakukan oleh aparat pemerintah harus dinyatakan "batal seluruhnya" (absolute nietig) atau "batal demi hukum" (nietig van rechts wege). Jika tidak memenuhi syarat relatif maka suatu perbuatan hukum yang dilakukan oleh aparat pemerintah harus dinyatakan "dapat dibatalkan" (vernietig baar).

Seorang filosof Jerman bernama Immanuel Kant mengatakan bahwa hukum seperti dua sisi suatu mata uang logam, pada salah satu sisi terdapat nilai "kebenaran menurut hukum" (recht matig) sedangkan disisi yang lain terdapat nilai kemanfaatan bagi rakyat (doel matig). Jika 
kedua aspek tersebut bertentangan maka hakim harus mengutamakan aspek kemanfaatan bagi rakyat (doel matig).

Untuk lebih jelasnya, berikut perbandingan dari ketiga teori kebatalan tersebut Batal Mutlak (absolute nietig). Secara prinsip, batal mutlak berakibat semua perbuatan yang pernah dilakukan, dianggap tidak pernah ada. Dalam konteks ini, perbuatan yang dinyatakan tidak pernah ada tersebut, berlaku prinsip fiction theory atau semua orang atau subjek hukum dianggap tahu hukum. Dalam hal batal mutlak ini, yang berhak menyatakan batal batal mutlak hanyalah peradilan dalam Undang-Undang Kehakiman. ${ }^{9}$

1. Batal Demi Hukum (nietig van recht wege)

Akibat hukumnya ada dua alternatif. Alternatif pertama ialah perbuatan yang sudah dilakukan, dianggap tidak ada atau tidak sah secara hukum, dan alternatif kedua ialah perbuatan yang telah dilakukan, sebagian dianggap sah, dan sebagian lagi dianggap tidak sah. Dalam hal batal demi hukum ini, pejabat yang berhak menyatakan batal atau tidak adalah pihak yudikatif dan eksekutif.

3. Dapat Dibatalkan (vernietig baar)

Dalam hal ini, dapat dibatalkan memiliki konsekuensi hukum dimana keseluruhan dari perbuatan hukum yang pernah dilakukan sebelumnya, tetap dianggap sah. Artinya, keseluruhan perbuatan di masa lampau tetap menjadi suatu tindakan hukum yang tidak dapat dibatalkan atau tetap berlaku pada masa itu. Adapun pejabat yang berhak membatalkan adalah pihak yudikatif, eksekutif dan legislatif

\section{PENUTUP}

Perbuatan pemerintah yang termasuk dalam perbuatan hukum dapat berupa : perbuatan hukum menurut hukum privat dan perbuatan hukum menurut hukum publik. Perbuatan hukum menurut hukum privat dalam hukum tata pemerintahan terjadi perdebatan apakah merupakan lapangan ilmu hukum tata pemerintahan atau bukan. Namun yang dibahas dalam lingkup hukum tata pemerintahan yakni perbuatan hukum menurut hukum publik.

$9 \quad$ E.Utrecht. 1986, Pengantar Hukum Administrasi Negara Indonesia. Pustaka Tinta Mas. Surabaya. Hlm 109-113. 
Akibat Hukum kewenangan yang tidak sah ialah batal demi hukum, begitu juga dengan Akibat Hukumnya perbuatan hukum aparat pemerintah yang dinyatakan batal demi hukum pada mulanya didasari dengan kewenangan yang tidak sah dan tidak memenuhi syarat-syarat ketentuan yang harus terpenuhi agar suatu perbuatan aparat pemerintah dinyatakan sah. Dalam batal demi hukum terdapat dua alternatif yakni akibat hukum atau sanksi berupa semua perbuatan yang dilakukan dianggap belum pernah ada sehingga segala sesuatunya harus dikembalikan seperti sedia kala atau alternative kedua memakai batal nisbi yakni sebagian perbuatan dianggap sah dan sebagian lagi diputuskan batal.

\section{DAFTAR PUSTAKA}

E.Utrecht. 1986, Pengantar Hukum Administrasi Negara Indonesia. Pustaka Tinta Mas. Surabaya.

Iskatrinah, Pelaksanaan Fungsi Hukum Administrasi Negara Dalam Mewujudkan Pemerintahan Yang Baik, Litbang Pertahanan Indonesia, Balitbang DepHan 2004.

Eman Suparman, makalah "Badan Peradilan Untuk Keputusan Birokrasi”, http://resources.unpad.ac.id/unpadcontent/uploads/publikasi_dosen/2K\%20Pengantar-UU-TUN-FoMed.pdf, diakses 12 Juli 2017

Soehino, 1999, Ilmu Negara, Liberty, Yogyakarta, .

Hassan Suryono, 2008, Ilmu Negara Suatu Pengantar ke Dalam Politik Hukum Kenegaraan, UNS Press, Surakarta,

Miriam Budiardjo, 2005, Dasar- Dasar Ilmu Politik, Gramedia Pustaka Tama, Jakarta

Winahyu Erwiningsih, makalah "Peranan Hukum dalam Pertanggung jawaban Perbuatan Pemerintahan (Bestuurshandeling) Suatu kajian dalam Kebijakan Pembangunan Hukum".

Iskatrinah, Pelaksanaan Fungsi Hukum Administrasi Negara Dalam Mewujudkan Pemerintahan Yang Baik, Litbang Pertahanan Indonesia, Balitbang Dep Han 2004. 